Bonifacy Miazek

Breitenfurth k. Wiednia

\title{
POMOC DLA POLSKICH EMIGRANTÓW W WIEDNIU W LATACH 1980-1989
}

O genezie polskiej emigracji w latach 1980-1989 powstało już wiele prac źródłowych oraz syntez polityczno-socjologicznych ${ }^{1}$. Dysponujemy też wieloma znakomitymi utworami z zakresu literatury pięknej: pamiętnikami, wspomnieniami, poezją, powieścią i dramatem ${ }^{2}$. W suchych analizach politycznych i ekonomicznych oraz w literaturze pięknej zamknięto losy tysięcy ludzi wyrzuconych na obce brzegi. Ludzi oszukanych, zaszczutych policyjnym terrorem, podsłuchami, aresztami, wyrokami kolegiów lub sądów wojskowych. Nie była to wyłącznie emigracja za chlebem, jak często próbuje się ten problem przedstawić. Była to na ogół ucieczka ludzi młodych, wykształconych, z dyplomami uniwersyteckimi, którym nie brakowało w Polsce chleba, ale zabrakło dla nich wolności. Tego podstawowego środka, aby człowiek mógł żyć i mógł się właściwie rozwijać we własnym kraju, we własnym środowisku i kulturze. Tę wolność chcieli mieć na własnej ziemi. Zaświadczają to najpełniej historyczne daty: Poznań 1956, Gdańsk 1970, Radom 1976, czy wreszcie daty najbliższe, jakie wprowadzają nas w tematykę referatu - sierpień 1980 w Stoczni Gdańskiej. Powstanie „Solidarności".

Właśnie od daty 1980 roku należałoby zacząć omówienie różnych form pomocy polskim emigrantom w Wiedniu. Według statystyk stan

1 Wynotowuję pozycje znane mi osobiście z lektury: J. Karpiński, Dziwna wojna, Paryż 1990; Z. Korybutowicz, Grudzień 1970, Paryż 1983; M. Łopiński, M. Moskwit, M. Wilk, Kompira. Rzecz o podziemnej „Solidarności”, Gdańsk-Warszawa 1989; A. Paczkowski, Wojna polsko-jaruzelska, Warszawa 2006; Praca zbiorowa: Prawa człowieka i obywatela w PRL w okresie stanu wojennego, Paryż 1983; J. Topolski, Polska, Europa, świat. Historia 1939-1998, Warszawa 2000; Z. Paczkowski „Solidarność" olsztyńska w stanie wojennym i w latach następnych (1981-1989), Olsztyn 2001.

2 K. Brandys, Miesiace (1980-1981), Paryż 1982; R. Bugajski, Przestuchanie, Paryż 1983; Z. Herbert, Raport z oblężonego miasta i inne wiersze, Paryż 1983; G. Herling-Grudziński, Dziennik pisany noca (1980-1983), Paryż 1984; M. Nowakowski, Raport o stanie wojennym, Paryż 1982. 
wojenny z 13 grudnia zastał w Wiedniu i jego okolicach około 30 tysięcy Polaków ${ }^{3}$.

Po ogłoszeniu stanu wojennego 13 grudnia 1981, Wiedeńczycy spontanicznie, przez nikogo jeszcze nie zachęcani, pośpieszyli z wielką pomocą dla naszych rodaków. Zaczęło się od polskiego Kościoła na Rennwegu 5. Zakrystia i korytarze w przeciagu kilku dni były zapchane paczkami. Ludzie przynosili pościel, ubrania, buty, żywność, pieniądze dla Polaków. Wiele austriackich rodzin zaofiarowało swoje mieszkania. Wtedy również powołano organizację Polenhilfe, która przychodziła z pomocą przez następne lata potrzebującym emigrantom, lecz również Polakom w kraju. Rząd austriacki ogłosił wtedy zbiórkę pieniędzy dla Polaków, zaznaczając, że z funduszy państwowych doda drugie tyle do zebranej sumy. Zebrano wtedy ponad 25 milionów szylingów.

Niestety, moje wiadomości nie są pełne, i nie mogą być pełne, ponieważ nie dysponuję $\mathrm{w}$ tym przedmiocie szerszymi opracowaniami, a kwerenda po austriackich archiwach i urzędach $\mathrm{z}$ obecnego mojego miejsca zamieszkania jest niemożliwa. Materiały, jakie pragnę na tym miejscu przedstawić to przede wszystkim własne świadectwo o tej pomocy, której byłem naocznym świadkiem, i kilkanaście faktów - dziś już o znaczeniu dokumentu - jakie otrzymałem w tej kwestii od pani prof. Joanny Ziemskiej z Wiednia i od ks. Edwarda Lipca, obecnie proboszcza w Waldzell, który wtedy był wikariuszem w polskim kościele na Rennwegu. W jednym przypadku korzystam również z krótkiej notatki, zamieszczonej w „Kulturze" paryskiej, której autorem był Marian Gomółka, nieżyjący już działacz Wiedeńskiej Polonii. Posłużę się też w kilku wypadkach faktami, zaczerpniętymi ze źródłowo opracowanej książki Władysława Stanisława Kucharskiego Polacy i Polonia w rdzennej Austrii w XIX i XX wieku, Lublin-Wiedeń 1994 oraz pracą Franciszka Malinowskiego Austriackie mass media o Polakach w latach 80.: Polonia i przyjaciele Polski w Austrii, red. Władysław S. Kucharski, Lublin 1995.

Muszę zacząć od tego, że już przed sierpniem 1980 rozpoczął się wzmożony napływ Polaków do stolicy Austrii. W pewnym sensie przyjazd ten był ułatwiany, bo od roku 1972 zniesiono dla Polaków wizy. Jak nadmieniłem wyżej stan wojenny z 13 grudnia zastał w Wiedniu i jego okolicach około 30 tysięcy Polaków.

Oczywiście, nie wszyscy chcieli emigrować. Wielu było takich, których zaskoczyło ogłoszenie stanu wojennego, którzy nie mogli wracać do kraju, gdzie internowano tysiące członków „Solidarności”, gdzie rząd wyprowadził na ulice miast wojsko i czołgi przeciwko robotnikom. Ge-

\footnotetext{
${ }_{3}^{3}$ Polacy w Austrii: www.zakorzenienie.most.org.ol/za_1 1/08.htm
} 
nerał Jaruzelski co prawda zapowiadał kontynuację "odnowy”, zapewniał, że nastąpi reaktywowanie "Solidarności", ale nikt z normalnych ludzi nie wierzył takim obietnicom. Były one przecież już nieraz składane w latach poprzednich zrywów, aby w rezultacie jeszcze bardziej po opanowaniu sytuacji zacisnąć policyjną obrożę.

$\mathrm{Na}$ ten temat napisano już wiele głębokich analiz politycznych, socjologicznych i gospodarczych. Ale wspominam o tych wydarzeniach, ponieważ tam właśnie leży przyczyna szerokiej fali emigracyjnej z Polski. Nasilenie emigracji nastąpiło właściwie po zniesieniu stanu wojennego, w Austrii znalazło się wtedy ponad 60 tysięcy Polaków. Należało tym ludziom zapewnić dach nad głową wyżywienie, wszelką inną pomoc potrzebną do życia. W tej sytuacji z wielką pomocą pośpieszył w Austrii Kościół. Caritas austriacki udostępnił na terenie całego kraju instytucje parafialne, jakie mogły przyjąć uchodźców. Były to domy parafialne, przedszkola i szkoły, a nawet domy prywatne, gdzie umieszczano emigrantów.

Głównym punktem zbiorczym dla Polaków - w początkowej fazie wielkiego naporu - był polski kościół w trzeciej dzielnicy Wiednia przy Rennweg 5, w pobliżu dworca południowego. Rektorem kościoła i duszpasterzem dla Polonii w Austrii był ks. Jerzy Walkusz ze Zgromadzenia Księży Zmartwychwstańców. Współpracowali z nim wtedy: ks. Edward Lipiec (studiował katechetykę na Uniwersytecie Wiedeńskim), ks. Tadeusz Kondrowski, ks. Władysław Dymny, ks. Jan Mazurek i ks. Kazimierz Wójtowicz (również studia - z zakresu teologii pastoralnej i literatur słowiańskich). Trzeba też wspomnieć tutaj o polskim kościele na Kahlenbergu, którego rektorem był ks. Piotr Kaglik, współpracował z nim ks. Stanisław Szulhaczewicz. Cały ten zespół dwoił się i troił, aby sprostać wszystkim potrzebom i trudnościom, związanym z zakwaterowaniem tysięcy ludzi. Szczególnym charyzmatem odznaczył się wtedy ks. Edward Lipiec. Jeździł starym samochodem (chyba był to „moskwicz”) dziesiątki, a nawet setki kilometrów do odległych obozów dla uchodźców w Grazu, Wlach, Klagenfurt, w Innsbrucku, Salzburgu, w Linzu i wielu innych miejscowościach.

Pamiętam jedną z takich wypraw, zima, w Wielkim Poście, jechaliśmy do Götzendorf, gdzie miałem mu pomóc w spowiedzi. Samochód, widocznie niezbyt świadomy naszej charytatywnej misji odmówił posłuszeństwa gdzieś kilka kilometrów przed celem. Ani gorączkowe poszukiwania przyczyn w motorze (ks. Edward), ani gorące modlitwy do świętego Antoniego (ja), nie pomogły. Musieliśmy iść pieszo, targając jeszcze dwa worki z darami dla dzieci. Księdzu Edwardowi dostały się słodycze, jako że był młodszy i silniejszy, ja dźwigałem przeróżne zabawki dla dzieci, w większości chyba stare, wyłysiałe misie. Paczki 
z żywnością i innymi darami pozostały w samochodzie. Przyjechały później. Dwaj młodzi Polacy wkrótce uruchomili silnik.

Kiedy mówię o pomocy polskiego kościoła w Wiedniu chciałbym też dodać, że poprzez Zgromadzenie Księży Zmartwychwstańców dochodziło do wielu kontaktów z austriackimi duchownymi. Godzi się tu wspomnieć chociażby o szpitalu Ojców Bonifratrów w Wiedniu, którego przeorem w owym czasie był O. Albrich Csapcsar, pochodzący z Cieszyna. Przyjmował on bezpłatnie i leczył setki polskich emigrantów, ale także zatrudniał w szpitalach Bonifratrów polskich lekarzy i polskie pielęgniarki ${ }^{4}$. Mówiąc o pomocy polskiego kościoła nie mogę zapomnieć o nazwisku Jadwigi Rogowskiej, która była kucharką na Rennwegu. Emigranci zawdzięczają jej bardzo wiele. Gotowała, karmiła, opiekowała się małymi dziećmi, wydawała lekarstwa, zawsze niezastąpiona, zawsze najbardziej potrzebna w obrębie polskiego domu. O każdej porze dnia i nocy służyła ludziom. $Z$ pewnym żalem zaznaczę tutaj, że ta ofiarna kobieta nie dostała za swoją pomoc żadnego odznaczenia, podobnie zresztą jak i ks. Edward Lipiec.

Kiedy zbierałem materiały do tego tekstu, zwróciłem się do niego z prośbą o kilka faktów, jakie zapamiętał z tamtych lat. W liście, datowanym 17 sierpnia 2009 pisze: „Podziwiam Austriaków. Na wspomnienie ich bezinteresownej pomocy lat osiemdziesiątych, jeszcze dziś fala ciepła wypełnia moje serce. Tyle wyciągniętych rąk z darami dla nieznanych, obcych ludzi. Tyle Życzliwości i poświęcenia. Ci ludzie, którzy nam wtedy pomagali nie byli jakimiś bogaczami. Oni dzielili się tym, co mieli, tyle co również dla nich samych było potrzebne. Dla nas Polaków znosili niewygody, bardzo często przyjmującobcych ludzi do swoich mieszkań [...] Pamiętam wyjazd do St. Peter/Murau, w południowej Austrii, Steiermark, w Wielki Post, Anno Domini 1982. Msza św. miała być o godz. 15.00. Przyjechałem z akademickim opóźnieniem. W kościele długa kolejka przed konfesjonałem, ponad 200 osób, w większości młodych mężczyzn. Sytuacja wyjątkowo trudna. Nie wiem, czy wyspowiadałem połowę, bo o godzinie 18.00 musiałem mieć drugą Mszę św. w odległym o $80 \mathrm{~km}$ Villach. Co robić? Pouczyłem o warunkach absolucji generalnej, na jaką pozwala Kościół tylko w wyjątkowych przypadkach, zrobiłem z nimi akt żalu i udzieliłem generalnej absolucji. Jedyny raz $\mathrm{w}$ tej formie $\mathrm{w}$ moim kapłańskim życiu. Tych umęczonych, a przecież jasnych twarzy nigdy chyba nie zapomnę" ${ }^{\prime \prime}$.

${ }^{4}$ W. St. Kucharski, Polacy i Polonia w rdzennej Austrii w XIX i XX wieku, Lublin-Wiedeń 1994, s. 371. Na tym miejscu pragnę serdecznie podziękować prof. Krzysztofowi Kuczyńskiemu z Uniwersytetu Łódzkiego za pomoc w zdobywaniu potrzebnej, i bardzo często trudno dostępnej literatury przedmiotu.

${ }^{5}$ Ks. E. Lipiec, List do autora artykułu, datowany Waldzell 17.8.2009. 
Ze świadectw prywatnych przytoczę teraz informacje prof. Joanny Ziemskiej: „Osobiście wiem, że na terenie Wiednia było kilka punktów Polenhilfe. $Z$ reguły pracowali tam wolontariusze, a wielu wypadkach rodowici Austriacy bez żadnego powiązania z Polską. Sama miałam przyjemność poznać kilka takich pań w wieku emerytalnym, zajmujących się pomocą i poradnictwem dla Polaków. Niektóre z nich zapisały się nawet na kurs języka polskiego w Volkshochschule, aby móc lepiej komunikować się ze swoimi podopiecznymi. Wówczas w Wiedniu wiele było oferowanych takich kursów. Z tego, co wiem, część z nich była finansowana przez rząd austriacki. W Polenhilfe pracowało też sporo osób z Polonii. Również sporo studentów pracowało bezpłatnie dla tej instytucji.

Kilka hoteli wiedeńskich ( $\mathrm{w}$ tym m.in. hotel Laxenburg i hotel Columbus w10 dzielnicy) zostało przeznaczonych dla uchodźców z Polski. Organizowane były intensywne kursy języka niemieckiego dla tych osób. Zostałam zaangażowana jako lektor języka niemieckiego właśnie dla osób zakwaterowanych w tych dwóch hotelach. Była to spora grupa ludzi w różnym wieku, od pana w wieku emerytalnym po niemowlęta, ale oczywiście w przeważającej większości to ludzie młodzi.

Kursy odbywały się codziennie 4 godziny - od 9.00 do 12.00. Kursanci dostawali podręczniki, były też taśmy i specjalnie urządzone laboratorium fonetyczne. Ja uczyłam dwa razy w tygodniu, a koleżanka (Barbara Lefik) 3 razy, względem na odwrót, bo zamieniałyśmy się co tydzień. Nadmieniam, że nauka nie była łatwa, ponieważ była spora rozpiętość wykształcenia uczestników. Z wyższym, średnim (najczęściej technicznym) i z podstawowym, i jak już wspomniałam - w różnym wieku. Większość nie znała oprócz polskiego żadnego języka. Do lekcji przygotowywałyśmy się solidnie. Zależało nam na tym, aby tych ludzi zainteresować i czegoś nauczyć. Sporo było młodych małżeństw z dziećmi. Dzieci chodziły do szkoły, względnie miały zacząć chodzić od jesieni. Trzy popołudnia $\mathrm{w}$ tygodniu przeznaczone były na lekcje $\mathrm{z}$ dziećmi. Były to zajęcia w wymiarze dwóch godzin. I tutaj sytuacja dydaktyczna była nie łatwa. Najstarsze dzieci miały lat 13 lub 15, najmłodsze szły właśnie do przedszkola. Przy dzieciach moja rola polegała na tym, aby dzieciom uczęszczającym do szkoły pomagać przy odrabianiu lekcji. W pierwszym rzędzie tłumaczyć im sens poszczególnych ćwiczeń. Inne dzieci należało w tym czasie zająć rysunkami albo jakąś grą zespołową. Kiedy indziej należało im opowiadać bajeczki, ilustrując to jakimś obrazkiem, najpierw w języku polskim, potem to samo, ale już krócej - po niemiecku, zwracając szczególną uwagę na powtórzenie kilku wyrazów, których chciałam nauczyć.

«Moja» grupa, podobnie jak wszystkie inne tego rodzaju, miały opiekunów z urzędu. Były to osoby z urzędu do spraw młodzieży, urzędu 
do spraw emigrantów, pracownicy socjalni, lekarze, itp. Osoby te przychodziły regularnie do hoteli, bo zawsze było coś do załatwienia. Do naszych obowiązków należało także tłumaczenie rozmów między tymi osobami, i ich podopiecznymi.

Niestety, nie bardzo już teraz pamiętam, jak długo trwały te kursy. Z pewnością kilka dobrych miesięcy. Po zakończeniu kursu, uchodźcy - w zależności od zawodu - otrzymywali oferty pracy. Pamiętam, że dwie rodziny wyjechały do Voralbergu, jedna do Styrii (Steiermarkt), dwie do Dolnej Austrii. Najdziwniejsze było to, że najszybciej pracę dostała najstarsza kursantka (i najgorsza językowo) - pani Krystyna, lat ok. 55, a może i więcej, z zawodu dyplomowana pielęgniarka, wyspecjalizowana do pielęgnacji starszych osób. To właśnie ona, wraz z mężem emerytem, opuściła hotel jako pierwsza, otrzymując mieszkanie i pracę w zawodzie, w domu starców.

Przez jakiś czas utrzymywałam jeszcze kontakt z kilkoma osobami, z innymi kontakt urwał się zaraz po wyjeździe. Jedno z moich „dzieci” jest dzisiaj urzędnikiem w austriackich kolejach federalnych w Dolnej Austrii. Dowiedziałam się też o kilku rozwodach i kilku ślubach. Wszystko, mniej lub więcej normalne koleje życia...

Na zakończenie muszę nadmienić, że bardzo dużo Polakom pomagał Kościół, wyjątkowo ofiarnie i z wielkim zaangażowaniem w różnych częściach Austrii. Organizowane były przeróżne imprezy charytatywne. A uzyskany zysk przeznaczony był na pomoc dla Polaków. Jak sobie przypominam Caritas w Graz-Sekau zorganizował „Steirische Polenhil$\mathrm{fe}^{\prime \prime}$, podobnie było w Salzburgu.

Może jeszcze kilka słów na temat moich rodziców. Niestety, nie mogę ich już zapytać o tamtą działalność, sami nigdy tym nie chwalili się specjalnie. Wiem natomiast, że byli bardzo zaangażowani w pomoc dla Polaków. Mama chodziła do różnych ministerstw i urzędów dzielnicowych w celu uzyskania mieszkań lub innych rodzajów pomocy. Poza tym rodzice zbierali żywność i ubrania dla ludzi w Polsce, i z pomocą gmin przesyłano te dary do kraju. Byli też zaangażowani politycznie. Brali udział w przerzutach polskich wydawnictw emigracyjnych, a także części zamiennych do powielaczy.

Tyle wiem na pewno" ${ }^{\prime 6}$.

Były to świadectwa ludzi żyjących, których dobrze znam i którzy cieszą się wielkim autorytetem wiedeńskiej społeczności polskiej. Ostatni

${ }^{6}$ J. Ziemska, List do autora artykułu, datowany Wiedeń 26.8.2009. Uzupełnię nieco informacje o rodzicach prof. Joanny Ziemskiej. Ojciec, Jerzy Wandel, więzień Pawiaka i hitlerowskich obozów koncentracyjnych, matka Maria Wandel - to zasłużeni działacze Polonii Wiedeńskiej, którzy dali się poznać w pracy społecznej w Klubie Stowarzyszenia Polskiej Kultury (lata 1980-1989) ale i w latach późniejszych, bo potrzebujących wśród polskich uchodźców zawsze nie brakowało. 
tekst zacytowałem nieco obszerniej, ponieważ traktował o problematyce szkoły i nauczania polskich dzieci w Wiedniu. A właśnie o tych sprawach mamy bardzo skąpe wiadomości w dostępnej mi literaturze.

Nawiązując poniekąd do nazwisk ludzi osobiście mi znanych, posłużę się teraz tekstem zamieszczonym w „Kulturze” paryskiej, w numerze majowym z roku 1982, w którym Marian Gomółka, znany polski działacz emigracyjny w Wiedniu, odnotował sporą garść faktów o pomocy dla polskich uchodźców. W artykule zatytułowanym Kronika austriacka podaje:

„Ministerstwo Spraw Zagranicznych Austrii zwróciło się do Polsko-Amerykańskiego Komitetu Pomocy Emigrantom (biuro tego urzędu znajdowało się w 1 dzielnicy, obok Hauptpost, przy Postgasse 14, a jego dyrektorem był wtedy Andrzej Balko - B.M.) z prośbą o pomoc w wyszukaniu rodzin polskich, przebywających w Austrii, a mających członków najbliższej rodziny w Polsce, celem ułatwienia tym rodzinom sprowadzenia ich najbliższych w ramach łączenia rodzin. Rząd Austrii na drodze dyplomatycznej uzyskał zgodę na przyjazd w kilku wypadkach małoletnich dzieci. Wiedeńskie Stowarzyszenie Polskiej Kultury (SPK) przekazało na rzecz Polaków 50 tysięcy szylingów, 250 kg odzieży, oraz 150 kg żywności. Rzecznik USA do spraw uchodźców oświadczył, że Stany Zjednoczone, które przed 13 grudnia brały 50 procent z ogólnej liczby uchodźców Austrii, po tej dacie biorą 90 procent z ogólnej liczby ubiegających się o emigrację. Z Salzburga odszedł 31 marca 165. transport Caritasu z 17 tonami żywności do Poznania. Tamtejszy Caritas należy do najbardziej czynnych organizacji w akcji pomocy Polakom. Akcja wysyłania paczek do Polski nie słabnie. Tylko jedna firma wysyła dziennie 1200 paczek, 10-20 kilogramowych. Koszt wysyłki wynosi 130 szylingów. Paczki dowozi się ciężarówkami do Krakowa, Katowic i Warszawy, i doręcza adresatom za pokwitowaniem. Odbiorców zamieszkałych dalej niż $30 \mathrm{~km}$ od wyżej wymienionych miast zawiadamia się o nadejściu paczki pocztą"7.

Wymienione już wyżej Stowarzyszenie Polskiej Kultury (właściwa nazwa Stowarzyszenie Polskich Kombatantów). Zostało założone w Wiedniu, w listopadzie $1963 \mathrm{r}$. i podlegało centralnym władzom w Londynie. Uroczystego poświęcenia dokonał ks. bp Władysław Rubin 30 stycznia 1964 r. W chwili utworzenia, Stowarzyszenie liczyło zaledwie 20 członków, nigdy tez nie przekroczyły liczby 50. Członkowie stanowili poniekąd elitę, rekrutowali się bowiem z byłych więźniów obozów koncentracyjnych, żołnierzy Polskich Sił Zbrojnych walczących na Zachodzie, byłych żołnierzy Armii Krajowej. Członkowie tej organizacji wraz z Polenhilfe, wysłali do Polski w początkach lat osiemdziesiątych wiele transportów

7 M. Gomółka, Kronika austriacka, „Kultura” Nr 5/416, Paryż 1982, s. 149. 
żywności, odzieży, leków i sprzętu medycznego, głównie do szpitali i domów dziecka. Akcja niesienia pomocy Polakom, jak pisze Władysław Stanisław Kucharski w książce Polacy i Polonia w rdzennej Austrii w XIX i XX w. (1994), nabrała szczególnie dużego rozmachu po zniesieniu stanu wojennego. W tym bowiem czasie i w latach późniejszych na apel SPK, Austria wysłała do Polski indywidualnym rolnikom kilka tysięcy nowych albo wyremontowanych maszyn rolniczych, oraz setki ton nawozów sztucznych ${ }^{8}$.

$\mathrm{Te}-\mathrm{z}$ pewnością fragmentaryczne i niepełne - wyliczenia pomocy dla polskich emigrantów, jak również dla Polski w ogóle, zakończę informacją jaką Polenhilfe oraz założony w Wiedniu przez Austriaków „Komitee Solidarität mit Solidarność" wspierała politycznych uchodźców. Komitet ten wydawał pismo „Polen Information”, informujące szeroko o sprawach politycznych i ekonomicznych naszego kraju. W ramach tego Komitetu działali emigranci polityczni z Polski, członkowie „Solidarności”, którzy z czasem wydawali „Polskie Wiadomości”, otrzymując do tego celu wszelką pomoc techniczną i materialną od Austriaków. Do redakcji należeli wtedy docent Włodzimierz Pianka, którego stan wojenny zastał w Jugosławii i który był zmuszony pozostać w Wiedniu, tam również został profesorem w Instytucie Slawistyki, dr Agnieszka Hofman-Pianka, a dalej: Andrzej Jaślikowski, Waldemar Stempkowski, Marian Czuryło i inni. Dalsze dzieje organizacji „Solidarność" na terenie Austrii komplikowały się później z powodu wewnętrznych różnic, ale ten problem dla naszego tematu ma już znaczenie dalsze.

Dotychczas eksponowałem tematykę pomocy nie wspominając nic o trudnościach, jakie z czasem napotykali emigranci. Niestety, były i takie. Rzeczowo wynotowuje te sprawy Franciszek Malinowski w pracy Austriackie mass media o Polakach w latach osiemdziesiatych. Nieśmiałe głosy krytyczne pojawiły się już zresztą pod koniec roku 1981. W „Neue Kronen Zeitung", z 13 listopada, Peter Gnam pisał:

Więcej niż pół miliarda szylingów będą nas kosztować w bieżącym roku polscy uchodźcy. Dotychczas ok. 23 tysięcy Polaków ubiegało się u nas o azyl. Codziennie przybywa następnych 150 osób. Oprócz tego w Wiedniu przebywa ponad 15 tysięcy Polaków jako „turyści”, podejmując "pracę na czarno" i rujnując nasz rynek pracy ${ }^{9}$. Więc i głosy o wprowadzenie wiz wjazdowych dla Polaków, co rzeczywiście nastąpiło już 8 grudnia 1981 roku.

Powoli zaczynał przygasać entuzjazm dla polskich uchodźców ze strony czynników państwowych. Jedynie Caritas austriacki kontynuował nadal swoją wielką pomoc. I aby znowu powołać się na pracę Fran-

8 W. St. Kucharski, Polacy i Polonia w rdzennej Austrii..., s. 342.

${ }_{9}$ F. Malinowski, Austriackie mass media o Polakach w latach osiemdziesiatych, w. Polonia i przyjaciele Polski w Austrii, pod redakcją Władysława S. Kucharskiego, Lublin 1995, s. 222. 
ciszka Malinowskiego: „Caritas wysłała do Polski w roku 1982 łącznie 160 ciężarówek z przyczepami, które przewiozły 3,3 tysięcy ton żywności i innych towarów wartości ok. 46 milionów szylingów. Dalsze 180 ton żywności, leków i odżywek dziecięcych, wartości 17 milionów szylingów wysłał Austriacki Czerwony Krzyż. Na koncie Austriackiego Komitetu Narodowego Pomocy Polakom zebrała się kwota 80 milionów szylingów"10.

Czyli co? Rząd swoje, a społeczeństwo swoje? Chyba tak. Ale dodajmy tu inną przyczynę, ważna, nawet bardzo ważną jak mi się wydaje, przyczynę która zmobilizowała raz jeszcze ludzkie masy: pielgrzymkę Jana Pawła II we wrześniu 1983, z okazji 300. rocznicy Odsieczy Wiedeńskiej. Powiało wtedy wielką falą sympatii dla Polaków. I tutaj kilka faktów, dotyczących co prawda głównie kultury i sztuki, ale zaświadczających tę sympatię. I tak: Austriacy owacyjnie przyjęli muzykę Krzysztofa Pendereckiego na głównym, uroczystym koncercie z okazji rocznicy zwycięstwa wiedeńskiego, na którym bardzo przyjazną pod adresem Polski mowę wygłosił ówczesny prezydent Austrii dr Rudolf Kirchschlager. Nagrodę państwową Austrii w zakresie literatury otrzymał Tadeusz Różewicz. Również wystawa prac Artura Grottgera i Piotra Michałowskiego, spotkała się z wielkim zainteresowaniem krytyki i mieszkańców Wiednia. Na rynku księgarskim ukazują się wtedy dwie ważne książki: Polnisches Wien Jakuba Forst-Battaglii oraz Jesień nadziei Władysława Bartoszewskiego.

Akcja charytatywna Caritasu została zakończona w lipcu 1983 roku, po zniesieniu w Polsce stanu wojennego. Instytucja ta wysłała do Polski od początków swojej działalności, tj. od lutego 1981 do marca 1983 - 330 transportów z darami, ok. 8 tysięcy ton artykułów spożywczych, leków i odzieży, o łącznej wartości 110 milionów szylingów.

${ }^{10}$ Ibidem, s. 224. Franciszek Malinowski jest autorem krytycznym. W pracy swojej referuje obiektywnie wszystko co poruszają austriackie media na temat Polski i Polaków. Przytoczony jego tekst mówi sam za siebie: „,W 1988 r. znów stał się aktualny problem polskich uchodźców. Pierwszą falę materiałów na ten temat dało się zauważyć w kwietniu, kiedy m.in. tygodnik „Wochenpresse” i kilka dzienników pisało, iż wskutek zniesienia wiz wjazdowych do Austrii zaczęły napływać rzesze polskich uchodźców. Od 9 maja wprowadzono tryb przyspieszony w sprawach azylowych Polaków i Węgrów w Austrii. Jak powiedział minister spraw wewnętrznych Karl Blecha na konferencji prasowej, z tych dwóch krajów nastąpił gwałtowny wzrost liczby osób pozostających w Austrii; z Polski był aż 18-krotny, przy czym 96 procent polskich uchodźców traktowało Austrię jako kraj tranzytowy do USA, Kanady i Australii. 88 procent przepytanych przez policję jako główny powód podawało niezadowolenie z sytuacji gospodarczej w swoim kraju, a tylko 7 procent przyczyny polityczne. Na początku lipca, w kolejnej fali materiałów prasowych, "Neue AZ" [6 VII] pisało o „rzece uchodźców w Traiskirchen, gdzie zostały osiągnięte granice możliwości”. Pielgrzymki nie docierały do Rzymu, kończyły się w Dolnej Austrii. „Kurier” opisywał strajk głodowy 66 Polaków, którym nie przyznano statusu uchodźcy politycznego. 26 czerwca APA poinformowała o demonstracji 100 Polaków, domagających się przyznania im azylu politycznego w Austrii" (s. 235). 


\section{Zusammenfassung}

\section{HILFSAKTION FÜR POLNISCHE EMIGRANTEN IN WIEN IN DEN JAHREN 1980-1989}

Der Aufsatz bespricht ankand von zahlreichen Bespielen vielfältige Formen der Hilfsaktion für polnishe Emigranten in Wien in den Jahrnen 1980-1989. In der Hauptsatz dt Österreichs lebten damals zi. 30.000-60.000 Polen. Nach dem 13. Dezember 1981 leisten wiele Wiener- unaufgefordert - ihre wertvolle Hilfe. Eine wesentliche Rolle spielten damals auch polnishe, in Österreich lebende und wirkende Geistliche. Der Verfasser, der damals Augenzeuge dieser wielen Hilfsaktionen gewesen ist, gibt vor allem zahlreiche Bespiele der uneigennützigen Hilfe von den österreichern an. Es waren Geldspenden, Kleider, Lebensmittel, übernachtungsmoglichkeitnen, Deuschkurse. Gegründet wurde auch die Organisation „Polenhilfe” (mit vielen Niederlassungen), die jahrelang den Wiener Emigranten, aber auch den Polen an der Weichsel, viel half. 